\title{
Choroby imitujące obraz kliniczny mózgowego porazenia dziecięcego
}

\author{
Conditions that manifest a clinical syndrome consistent with cerebral palsy
}

\author{
Barbara Słowińska-Jarząbek (iD), Barbara Steinborn (iD) \\ Katedra i Klinika Neurologii Wieku Rozwojowego UM im. K. Marcinkowskiego w Poznaniu \\ DOI:10.20966/chn.2020.58.459
}

\section{STRESZCZENIE}

Mózgowe porażenie dziecięce (MPD) jest najczęstszą przyczyną niepełnosprawności ruchowej wśród dzieci. Bardzo liczna populacja osób z MPD wymaga wielospecjalistycznej opieki. Wczesna identyfikacja chorych pozwala na jej optymalizacje, złagodzenie skutków diagnozy oraz pomaga osiągnąć chorym z MPD maksymalny potencjat funkcjonalny. Jednak postawienie diagnozy nie jest wystarczające. Przy dzisiejszym rozwoju medycyny, dostępności badań, chęć dążenia do poznania etiologii MPD jest rzeczą bezdyskusyjną. Samo rozpoznanie MPD jest jedynie przypisaniem do określonej grupy objawów klinicznych, niezwykle ważne jest także poznanie etiologii. Wiele chorób genetycznych oraz metabolicznych może prezentować objawy niepostępującego zaburzenia funkcji ruchowych, spełniających kryteria rozpoznania MPD. Choroby te należą niejednokrotnie do bardzo rzadkich, jednak nie należy ich wykluczać z diagnostyki różnicowej MPD. Dużą część z nich można zidentyfikować w sposób mało inwazyjny i na wczesnym etapie, dzięki programowi badań przesiewowych noworodków. Inne wymagają wykonania bardziej inwazyjnych procedur takich jak punkcja lędźwiowa. Neuroobrazowanie i molekularne testy genetyczne ułatwiają diagnozę i poznanie patofizjologii. Dla części tych chorób istnieje dostępna forma terapii. Dlatego też w przypadku pacjenta, który prezentuje objawy zespołu klinicznego MPD, przy braku udokumentowanych czynników ryzyka lub braku dowodu na trwałe uszkodzenie mózgu w badaniach neuroobrazowych na skutek urazu lub wrodzonych wad mózgowia, należy poszerzyć diagnostykę w poszukiwaniu chorób imitujących MPD. Celem niniejszej pracy jest zwrócenie uwagi na problem zaburzeń o etiologii genetycznej oraz metabolicznej, które klinicznie mogą przypominać MPD. Rozpoznanie MPD bez poszukiwania etiologii może prowadzić do nieefektywnej opieki nad pacjentem z dysfunkcją ruchową.

Słowa kluczowe: mózgowe porażenie dziecięce, diagnoza, niedowład spastyczny, ataksja, dystonia.

\section{ABSTRACT}

Cerebral Palsy (CP) is the most common cause of motor disorders among children. A very large population of people with $\mathrm{CP}$ requires multidisciplinary care. Early identification of patients leads to healthcare optimization, mitigations of symptoms and helps patients with $\mathrm{CP}$ to achieve their maximum functional potential. However, establishing a diagnosis is not sufficient. The aspiration to identify the etiology of CP is indisputable, especially nowadays, when a wide range of investigation methods is available. Although establishing diagnosis of CP is only an assignment to a specific group of clinical symptoms, it is also extremely important to identify the etiology. A number of genetic and metabolic diseases may demonstrate symptoms of non-progressive motor dysfunction that meet the diagnostic criteria of CP. These diseases are often very rare, however, they should not be excluded from the differential diagnosis of CP. A large number of underlying diseases can be identified in a minimally invasive way and at an early stage owing to newborn screening programs. The other ones require more invasive procedures, such as a lumbar puncture. Neuroimaging and molecular genetic investigations facilitate diagnosis and understanding of pathophysiology. Moreover, there are therapies available for some of these underlying diseases. Therefore, in the case of a patient presenting symptoms of the clinical syndrome of $\mathrm{CP}$, diagnostic should be extended to identify diseases mimicking $\mathrm{CP}$; particularly in the absence of documented risk factors or no evidence of permanent cerebral damage in neuroimaging studies due to trauma or congenital cerebral defects. The aim of this study is to highlight the problem of genetic and metabolic disorders that may clinically mimic CP. Establishing the diagnosis of $\mathrm{CP}$ without etiology investigations may result in ineffective care of patients with motor dysfunctions.

Key words: cerebral palsy, diagnosis, spasticity, ataxia, dystonia.

\section{WSTEP}

Mózgowe porażenie dziecięce (MPD) to grupa trwałych zaburzeń rozwoju ruchu i postawy, powodujących ograniczenie aktywności, które przypisuje się niepostępującym zaburzeniom mającym miejsce w rozwijającym się mózgu płodu lub niemowlęcia. Zaburzeniom aktywności ruchowej w MPD często towarzyszą zaburzenia czucia, percepcji, zaburzenia poznawcze, porozumiewania się i zachowania, padaczka oraz wtórne problemy mięśniowo-szkieletowe [1].

Mózgowe porażenie dziecięce jest najczęstszą przyczyną niepełnosprawności ruchowej wśród dzieci. Dane epidemiologiczne z Europy mówią o częstości występowania dziecięcego porażenia mózgowego na poziomie 1,5 do 2,5 na 1000 żywo urodzonych dzieci [2]. W Polsce częstość występowania MPD szacowana jest na 2,0-2,5 na 1000 żywo urodzonych dzieci [3].

Dane ze Stanów Zjednoczonych podają, iż częstość występowania MPD wśród 8-letnich dzieci wynosi 3 na 1000 [4], a około 764000 osób w Stanach Zjednoczonych żyje z objawami MPD [5]. Pod koniec XX wieku nastąpił wzrost częstości występowania MPD, co ma związek z kilkoma czynnikami, takimi jak zwiększony wskaźnik przeżywalności noworodków przedwcześnie urodzonych oraz zwiększona długość życia pacjentów z MPD [6]. Tak liczna populacja osób z MPD wymaga wielospecjalistycznej opieki. Wczesna identyfikacja chorych pozwala na optymalizację opieki, złagodzenie skutków diagnozy oraz 
pomaga osiągnąć chorym z MPD maksymalny potencjał funkcjonalny. Jednak postawienie diagnozy nie jest wystarczające. Przy dzisiejszym rozwoju medycyny, dostępności badań, chęć dążenia do poznania etiologii MPD jest rzeczą bezdyskusyjną. Samo rozpoznanie MPD jest jedynie przypisaniem do określonej grupy objawów klinicznych, niezwykle ważne jest także poznanie etiologii.

Wiele chorób genetycznych oraz metabolicznych może prezentować objawy niepostępującego zaburzenia funkcji ruchowych, spełniając w ten sposób kryteria rozpoznania MPD. Takie zaburzenia określane są jako choroby naśladujące obraz kliniczny MPD [7, 8]. Przy dążeniu do poznania etiologii nieprawidłowego rozwoju może się okazać, że w wielu przypadkach jest dostępne leczenie, które może zapobiec dalszym uszkodzeniom neurologicznym. Niezależnie od możliwości leczenia, wyniki badań genetycznych mogą być bardzo pomocne dla pacjenta $\mathrm{i}$ jego rodziny w ocenie ryzyka powtórzenia się wady u potomstwa w przyszłości, jak również w łagodzeniu niepokoju i poczucia winy, które często towarzyszą rozpoznaniu MPD [9].

W wielu przypadkach można szybko i jednoznacznie określić zaburzenia, które doprowadziły do MPD, które miały miejsce w rozwijającym się mózgu płodu lub noworodka. MPD jest najczęściej wynikiem przed-, okołoporodowego lub poporodowego procesu prowadzącego do uszkodzenia mózgu [10]. Najczęstszą przyczyną są powikłania wcześniactwa, zamartwica okołoporodowa, krwotok śródczaszkowy, infekcje, udar, kernikterus lub uraz okołoporodowy [11]. W przypadku pacjenta, który prezentuje objawy zespołu klinicznego MPD, przy braku udokumentowanych czynników ryzyka lub braku dowodu na trwałe uszkodzenie mózgu w badaniach neuroobrazowych na skutek urazu lub wrodzonych wad mózgowia, należy poszerzyć diagnostykę w poszukiwaniu chorób imitujących MPD.

Poniżej wymieniono cechy kliniczne, które powinny skłonić do poszukiwania przyczyn genetycznych i metabolicznych u pacjenta z objawami MPD:

- Ujemny wywiad w kierunku czynników ryzyka okołoporodowego uszkodzenia mózgu

- Choroby o podobnym obrazie klinicznym w rodzinie

- Nieprawidłowe objawy ruchowe pojawiające się po okresie prawidłowego rozwoju

- Regres rozwoju

- Postępujące objawy neurologiczne

- Napadowe objawy neurologiczne lub zmienność dobowa objawów

- Pogorszenie obrazu klinicznego w warunkach stanu katabolicznego

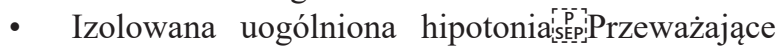
objawy ataksji

- Objawy obwodowej choroby nerwowo-mięśniowej

- Nieprawidłowe ruchy gałek ocznych (oculogyria ruchy rotacyjne gałek ocznych, zaburzenia ruchomości gałek ocznych, brak zdolności wykonywania dowolnych ruchów gałek ocznych, -napadowe sakkadowe ruchy gałek ocznych i głowy )
Celem niniejszej pracy jest zwrócenie uwagi na problem zaburzeń o etiologii genetycznej oraz metabolicznej, które klinicznie mogą przypominać MPD, co może skutkować rezygnacją z poszukiwania etiologii zaistniałych dysfunkcji ruchowych. Wybrane typowe przykłady zostaną przedstawione poniżej, pogrupowane według dominujących cech klinicznych.

Przegląd systematyczny na ten temat przedstawiono w pracy Leach i wsp. [7], a ciekawą propozycję sposobu diagnozowania dzieci z MPD przedstawił Pearson i wsp. w pracy „Genetic mimics of cerebral palsy” [8]. Zauważył on, że nie jest możliwe stworzenie kompletnego algorytmu diagnostycznego MPD, ale można zwrócić uwagę na pewne cechy kliniczne i wyniki badań, które pomogą odpowiednio ukierunkować lekarza klinicystę w poszukiwaniu etiologii. Na zamieszczonym diagramie przedstawiono propozycję ścieżki diagnostycznej po wykonaniu badań neuroobrazowych w przypadku pacjenta $\mathrm{z}$ cechami MPD (Ryc.1). W tabelach natomiast, propozycję badań biochemicznych i genetycznych w zależności od dominujących objawów imitujących MPD (Tabela I) oraz wybrane nieprawidłowości $\mathrm{w}$ badaniu rezonansem magnetycznym (MR) głowy u dzieci z podejrzeniem MPD, które mogą sugerować genetyczne podłoże obserwowanych objawów (Tabela II).

Ryc. 1. Propozycja ścieżki diagnostycznej po wykonaniu badań neuroobrazowych w przypadku pacjenta z cechami MPD.

*patrz Tabela I.

** patrz Tabela II.

Figure 1. General approach to some specific imaging findings that may orient the clinician toward an initial diagnostic testing strategy to the patient with suspected CP.

* See examples in Table I.

** See examples in Table II.

Historia/badanie neurologiczne nie wskazujące na MPD związane z okołoporodowym uszkodzeniem mózgu.

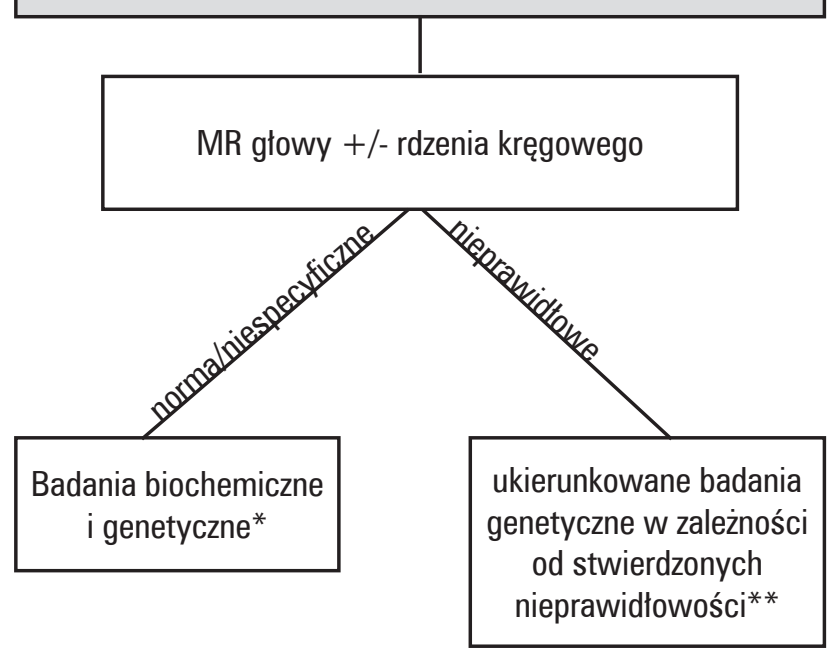


Tabela I. Propozycja badań biochemicznych i genetycznych w zależności od dominujących objawów imitujących MPD Table I. Biochemical and genetic investigations to consider in suspected CP, grouped by predominant clinical presentation.

\begin{tabular}{|c|c|c|c|}
\hline $\begin{array}{l}\text { opóźnienie rozwoju } \\
\text { u noworodka, mieszane } \\
\text { objawy ruchowe } \\
\text { developmental delay in } \\
\text { a newborn, mixed motor } \\
\text { symptoms }\end{array}$ & $\begin{array}{l}\text { dominująca spastyka } \\
\text { dominant spasticity }\end{array}$ & $\begin{array}{l}\text { objawy dystoniczne dystonic } \\
\text { symptoms }\end{array}$ & $\begin{array}{l}\text { dominujące objawy } \\
\text { ataksji } \\
\text { the dominant symptoms } \\
\text { of ataxia }\end{array}$ \\
\hline $\begin{array}{l}\text { - badania z surowicy } \\
\text { TSH, poziom kwasu } \\
\text { moczowego, aminokwasy, } \\
\text { mleczany, acylokarnityny, } \\
\text { aktywność biotynidazy } \\
\text { - badanie moczu } \\
\text { GCMS } \\
\text { - badanie płynu mózgowo } \\
\text { rdzeniowego } \\
\text { glukoza, mleczany, poziom } \\
\text { amin biogennych i GABA, } \\
\text { pteryny, 5-MTHF } \\
\text { - SNP-CGH microarray }\end{array}$ & $\begin{array}{l}\text { - badania z surowicy } \\
\text { amoniak, mleczany, } \\
\text { aminokwasy, } \\
\text { aktywność biotynidazy } \\
\text { - badanie moczu } \\
\text { GCMS } \\
\text { - badanie genetyczne } \\
\text { w kierunku dziedzicznej } \\
\text { paraplegii spastycznej } \\
\text { - SNP-CGH microarray }\end{array}$ & $\begin{array}{l}\text { - badania z surowicy } \\
\text { TSH, kwas moczowy, AFP, mleczany, } \\
\text { acylokarnityny } \\
\text { - badanie moczu } \\
\text { GCMS, puryny, pirymidyny, kreatyna } \\
\text { - badanie płynu mózgowo } \\
\text { rdzeniowego } \\
\text { glukoza, mleczany, poziom amin } \\
\text { biogennych i GABA, pteryny, 5-MTHF } \\
\text { - badanie genetyczne w kierunku } \\
\text { mutacji NKX2.1 (łagodna rodzinna } \\
\text { pląsawica) } \\
\text {-SNP-CGH microarray }\end{array}$ & $\begin{array}{l}\text { - badania z surowicy } \\
\text { AFP, mleczany, } \\
\text { aktywność biotynidazy } \\
\text { - badanie moczu } \\
\text { GCMS } \\
\text { - badanie } \\
\text { mitochondrialnego DNA, } \\
\text { poziom koenzymu } 010 \\
\text { - SNP-CGH microarray }\end{array}$ \\
\hline
\end{tabular}

TSH - hormon tyreotropowy, GCMS - profil kwasów organicznych w moczu, AFP- alfa-fetoproteina, GABA - kwas gammaaminomasłowy, 5-MTHF - 5-metylo tetrahydrofolian, SNP-CGH microarray - Analizy jednonukleotydowych polimorfizmów porównawcza hybrydyzacja genomowa do mikromacierzy.

Tabela II. Wybrane nieprawidłowości w badaniu MR głowy u dzieci z podejrzeniem MPD, które mogą sugerować genetyczne podłoże obserwowanych objawów.

Table II. Brain MRI findings suggestive of selected genetic CP mimics.

\begin{tabular}{|l|l|}
\hline \multicolumn{2}{|c|}{$\begin{array}{c}\text { Wybrane nieprawidłowości w badaniu MR głowy sugerujące podłoże genetyczne } \\
\text { Selected abnormalities in MRI of the head suggesting a genetic basis }\end{array}$} \\
\hline Hypomielinizacja & $\begin{array}{l}\text { - mutacja genu PLP1 (choroba Pelizeusa-Merzbachera, } \\
\text { Paraplegia spastyczna typu2 ) }\end{array}$ \\
& $\begin{array}{l}\text { - mutacja TUBB4A - H-ABC (Leukodystrofia } \\
\text { z hipomielinizacją oraz zanikiem zwojów podstawy i móżdżku) } \\
\text { - Zesp.Aicardiego-Goutieresa (zwapnienia podobne do } \\
\text { występujących w TORCH) }\end{array}$ \\
\hline Demielinizacja & $\begin{array}{l}\text { - Choroba Krabbego, } \\
\text { - leukodystrofia metachromatyczna }\end{array}$ \\
\hline Hipoplazja ciała modzelowatego & - dziedziczna paraplegia spastyczna \\
\hline Zmiany w gałce bladej & $\begin{array}{l}\text { T2 - hipointensywne } \\
\text { - NBIA (BPAN, MPAN), Fukozydoza } \\
\text { T2 - hiperintensywne } \\
\text { - kwasica metylomalonowa, deficyt dehydrogenazy } \\
\text { pirogronianowej, niedobór kreatyny }\end{array}$ \\
\hline Ogniskowa atrofia lub hipoplazja & $\begin{array}{l}\text { czołowo-skroniowa - acyduria glutarowa typu1 } \\
\text { móżdżek +/-skorupa - H-ABC (leukodystrofia } \\
\text { zipomielinizacją oraz zanikiem zwojów podstawy i móżdżku) } \\
\text { móżdżek - zespół Joubert }\end{array}$ \\
\hline \hline
\end{tabular}

TORCH - toksoplazmoza, różyczka, wirus cytomegalii, wirus opryszczki pospolitej i inne; NBIA - choroba neurozwyrodnieniowa z odkładaniem żelaza w mózgu; BPAN - neurodegeneracja związana z białkiem Beta-propeller; MPAN - neurodegeneracja związana z białkiem błony mitochondrialnej 


\section{WYBRANE CHOROBY Z DOMINUJĄCA SPASTYCZNOŚCIĄ.}

\section{Dziedziczna paraplegia spastyczna (hereditary spastic paraplegia, HSP).}

Istnieje ponad 80 genów związanych z HSP, chorobą, której cechą jest różnego stopnia niedowład spastyczny w obrębie kończyn dolnych [12]. W późniejszym stadium choroba może objąć również kończyny górne. Wyróżnia się postać czystą (niedowład i spastyczność kończyn dolnych, zaburzenia zwieracza pęcherza moczowego, zaburzenia czucia wibracji, hyperrefleksja w kończynach górnych) oraz złożoną (obecne inne objawy neurologiczne i ogólne, takie jak neuropatia obwodowa, zaburzenia funkcji poznawczych, ataksja, nieprawidłowy obraz mózgowia w badaniu MR). Istnieje znaczna heterogeniczność genetyczna i fenotypowa, a wiele genów może być powiązanych zarówno z postacią czystą, jak i złożoną [13]. W większości przypadków, lecz nie u wszystkich chorych, niedowład postępuje powoli. W szczególności HSP o początku w wieku niemowlęcym przebiegać może bez wyraźnej progresji [14]. W konsekwencji pacjenci z HSP mogą być zdiagnozowani jedynie jako postać diplegiczna MPD. Co może zasugerować HSP i zwrócić uwagę klinicysty, to brak okołoporodowych czynników ryzyka MPD, ścieńczenie ciała modzelowatego w badaniach obrazowych, oraz inne cechy towarzyszące postaci złożonej HSP, tj.parkinsonizm, ataksja, opadanie powiek, dystonia, oftalmoplegia, zwyrodnienie barwnikowe siatkówki, zaniki mięśni.

\section{Argininemia}

Jest to choroba dziedziczona autosomalnie recesywnie związana z deficytem arginazy. Spowodowana jest mutacją w genie ARG1. Skutkiem tego zaburzenia jest wzrost stężenia argininy oraz okresowy wzrost stężenia amoniaku w surowicy. Deficyt arginazy może objawiać się jako postępująca paraplegia spastyczna, w przeciwieństwie do innych zaburzeń cyklu mocznikowego, w których dominuje hiperamonemia oraz postępująca encefalopatia. Choroba zaczyna się w sposób podstępny w późnym niemowlęctwie, co może przyczyniać się do błędnej diagnozy MPD [15]. Dodatkowymi objawami klinicznymi mogą być padaczka oraz niepełnosprawność intelektualna, lecz dopiero pojawienie się ostrych objawów encefalopatii z wymiotami i hiperamonemią może nakierować lekarza na prawidłowe rozpoznanie. Diagnozę potwierdza wysoki poziom argininy w badaniu profilu aminokwasów w surowicy. Leczenie polega na ograniczaniu w pożywieniu białek, szczególnie tych zawierających argininę [16].

\section{Mnogi niedobór karboksylazy (multiple carboxylase deficiency, MCD)}

Ta wrodzona wada metabolizmu charakteryzuje się zmniejszoną aktywnością enzymów zależnych od biotyny. Można wyróżnić dwie różniące się klinicznie formy MCD: niedobór biotynidazy oraz niedobór syntetazy holokarboksylazy. Niedobór biotynidazy występuje częściej. Objawia się w późniejszym okresie niemowlęcym hipotonią, opóźnieniem rozwoju, napadami padaczkowymi, ataksją i kwasicą metaboliczną, a także wysypką skórną i łysieniem [17]. U niektórych pacjentów $\mathrm{z}$ niedoborem biotynidazy pojawia się spastyczność związana z mielopatią [18]. Natomiast niedobór syntetazy holokarboksylazy typowo objawia się we wczesnym okresie niemowlęcym ciężką kwasicą mleczanową, a inne objawy kliniczne to łojotokowa wysypka skórna, drgawki i encefalopatia. Cechy wzmożonego napięcia mięśniowego oraz opóźnienia rozwojowego mogą być błędnie interpretowane jako MPD [19]. Mnogi niedobór karboksylaz można wykryć w badaniu przesiewowym noworodków przy użyciu tandemowej spektrometrii mas. Dostępne jest leczenie polegające na podawaniu biotyny, co zapewnia ustąpienie objawów i kwasicy organicznej, a wczesne wdrożenie leczenia zapobiega niepełnosprawności i może zapewnić prawidłowy rozwój [20].

\section{WYBRANE ZESPOLY Z DOMINUJACYMI OBJAWAMI POZAPIRAMIDOWYMI/ DYSKINEZAMI}

\section{Zaburzenia metabolizmu amin biogennych}

Wrodzone zaburzenia metabolizmu amin biogennych i pteryn polegają na nieprawidłowej syntezie lub transporcie katecholamin (dopaminy, noradrenaliny, adrenaliny) oraz serotoniny. Objawy kliniczne są zróżnicowane i mają różny stopień nasilenia. Rozwój dzieci jest opóźniony. Chorzy mogą wykazywać objawy postępującej encefalopatii z napadami padaczkowymi, zespołu pozapiramidowego pod postacią dystonii, parkinsonizmu dziecięcego, kryz gałkoruchowych, objawy autonomiczne pod postacią ślinotoku i zaburzeń termoregulacji. Pacjent może być błędnie zdiagnozowany jako MPD z uwagi na niepostępujący charakter objawów motorycznych. Jednak szczególnie charakterystyczne objawy powinny budzić niepokój klinicysty: u chorych występują zaburzenia napadowe określane jako kryzy ocznozakrętowe (ang. oculogyric crises). Polegają one na zwrocie gałek ocznych ku górze, do boku lub ich konwergencji. Zazwyczaj towarzyszy im nieprawidłowa postawa odgięciowa w zakresie osi głowa-tułów i dystoniczna w zakresie kończyn. Świadomość w trakcie tych epizodów jest zachowana, a epizody mają tendencje do pojawiania się pod koniec dnia i ustępują po wyspaniu [21]. W diagnostyce konieczne jest oznaczenie stężenia aminokwasów, metabolitów amin biogennych oraz pteryn w płynie mózgowo rdzeniowym. Niedobór amin biogennych, w zależności od przyczyny, może być leczony podawaniem preparatów L-dopy, 5-hydroksytryptofanu oraz tetrahydrobiopteryny [22].

\section{Łagodna pląsawica dziedziczna (benign hereditary chorea, BHC)}

Jest to autosomalne dominujące zaburzenie ruchowe wynikające z mutacji genu NKX2.1 odpowiedzialnego za prawidłowy rozwój płuc, tarczycy i zwojów podstawy. Obraz kliniczny w przypadku tej mutacji obejmuje zakres od łagodnej dziedzicznej pląsawicy (BHC), po choreoatetozę, wrodzoną niedoczynność tarczycy i zespół niewydolności oddechowej noworodków [23]. Pełna triada objawów mózgowo-tarczycowo-płucnych występuje u 50\% chorych, u 30\% chorych objawy dotyczą mózgu i tarczycy, natomiast $13 \%$ ma izolowaną pląsawicę [24]. Pląsawica w BHC pojawia się najczęściej we wczesnym dzieciństwie i rozwija się do drugiej dekady życia, kiedy to zwy- 
kle objawy ulegają stabilizacji lub wycofują się. W okresie niemowlęcym występuje hipotonia, opóźniony rozwój ruchowy, ruchy pląsawicze. Badania neuroobrazowe są prawidłowe. Wywiad rodzinny w $1 / 3$ przypadków może być ujemny, co może skutkować błędną diagnozą MPD [25].

\section{Zespót Lesch-Nyhana}

Zespół ten jest rzadkim, związanym z chromosomem $\mathrm{X}$, zaburzeniem metabolizmu puryn, wynikającym z mutacji genu HPRT. Objawy są spowodowane całkowitym lub prawie całkowitym niedoborem fosforybozylotransferazy hipoksantynowo-guaninowej. Enzym ten uczestniczy w reakcji przemiany zasad purynowych: hipoksantyny i guaniny do monofosforanu inozyny i monofosforanu guanozyny. Przy jego braku dochodzi do nadmiaru hipoksantyny i guaniny, które następnie przekształcane są przez oksydazę ksantynową do kwasu moczowego. Zespół Lesch-Nychana charakteryzuje się zaburzeniami poznawczymi, motorycznymi i zachowania, u podłoża których leży hiperurykemia. Prowadzi do odkładania się kryształów kwasu moczowego w tkankach. W ciągu pierwszych miesięcy życia pojawiają się objawy związane z hipotonią i opóźnieniem rozwoju psychomotorycznego. Między 6 a 24 miesiącem życia rozwijają się objawy dotyczące górnego neuronu ruchowego, takie jak spastyczność i wygórowanie odruchów oraz objawy wskazujące na zajęcie układu pozapiramidowego, tj. dystonia (obejmująca mięśnie szyi, tułowia, żuchwy, ust), choreoatetoza i opistotonus. Najbardziej charakterystyczny objaw to samookaleczenie, gryzienia palców, rąk, warg i policzków, pojawia się on zwykle w 2 lub 3 roku życia. Dzieci z zespołem Lech-Nychana mogą być początkowo zdiagnozowane jako MPD, a dopiero pojawienie się samookaleczania pomaga wyznaczyć prawidłowy kierunek diagnostyki. Leczenie polega na podawaniu allopurynolu, co wpływa na zmniejszenie ryzyka rozwoju kamicy nerkowej, zapalenia stawów, jednak nie powoduje poprawy rozwoju i złagodzenia objawów motorycznych i samookaleczania się [26].

\section{Dyskinezy związane z ADCY5}

Choroby te są spowodowane mutacjami w genie ADCY5 kodującym cyklazę adenylową 5, enzym specyficzny dla prążkowia, kluczowy dla kilku szlaków metabolicznych. Objawy tej mutacji pojawiają się w okresie niemowlęcym lub wczesnodziecięcym jako osiowa hipotonia, opóźnienie rozwoju ruchowego i dyskinezy (pląsawica, balizm i choreoatetoza) często dotyczące mięśni twarzy. Charakterystyczne są epizody zaostrzeń po przebudzeniu, podczas zasypiania lub w trakcie infekcji, trwające od kilku minut do kilku godzin, a nawet dni. Mogą również występować uogólnione napady dystoniczne. Rozwój intelektualny może być prawidłowy. Przebieg choroby jest zmienny, może dojść do samoistnej poprawy w okresie dojrzewania. Pacjenci z dyskinezami związanymi z ADCY5 są często błędnie diagnozowani, a specyficzną wskazówką przybliżającą do rozpoznania są epizodyczne zaostrzenia dyskinez występujące podczas senności oraz rodzinne występowanie objawów [27].

\section{Kwasice organiczne}

Jest to grupa wrodzonych defektów metabolizmu aminokwasów i peptydów, w których dochodzi do kumulacji toksycznych kwasów organicznych i aminokwasów. We wszystkich typach acydurii obserwuje się uszkodzenie jąder podstawy, objawiające się wraz z kolejnymi zaostrzeniami choroby zespołem pozapiramidowym. Objawy mogą pojawić się kilka dni po urodzeniu jako ostra encefalopatia, lub później, jako nawracające zespoły zatrucia z zaburzeniami świadomości i kwasicą, przypominające klinicznie zapalenie mózgu, poprzedzone zwykle gorączką, infekcją, głodzeniem. Obraz kliniczny, wyniki badań neuroobrazowych i laboratoryjnych najczęściej od razu sugerują prawidłowe rozpoznanie kwasicy organicznej, jednak zdarza się również błędne rozpoznanie jako zapalenie mózgu z późniejszymi objawami pozapiramidowymi, imitującymi MPD. Prawidłowa diagnoza jest niezwykle ważna, gdyż daje możliwość rozpoczęcia leczenia żywieniowego [28].

\section{Zespoły mózgowego niedoboru kreatyny (cerebral creatine deficien- cies syndromes, CCDS)}

Do grupy schorzeń wynikających z zaburzeń biosyntezy i transportu kreatyny zaliczane są 3 jednostki chorobowe: dwie z nich to zaburzenia autosomalne recesywne - deficyt metylotrasferazy guanidynooctanu (GAMT) i deficyt amidynotransferazy arginina - glicyna (AGAT) oraz związany z chromosomem X deficyt transportera kreatyny (CRTR). Typowym objawem klinicznym jest upośledzenie umysłowe, opóźnienie rozwoju mowy i padaczka (60\%), poza tym hipotonia, ataksja oraz dystonia i pląsawica. Mimo, że objawy motoryczne są tutaj mniej widoczne, a główny problem to niepełnosprawność intelektualna, zburzenia zachowania i padaczka, warto pamiętać o tej grupie schorzeń, ponieważ w przypadku GAMT oraz AGAT istnieje w pełni skuteczne leczenie. Polega na doustnej suplementacji wysokodawkowym monohydratem kreatyny. U pacjentów z CRTR dodatkowo proponuje się suplementację aminokwasami: glicyną i argininą, efekty leczenia jednak nie są tak satysfakcjonujące [29, 30].

\section{Zespół niedoboru transportera glukozy typu 1 (GLUT1DS)}

Zaburzenia, wynikające $\mathrm{z}$ nieprawidłowego transportu glukozy przez barierę krew-mózg, związane są z mutacją w genie SLC2A1 i obejmują szereg różnych fenotypowo zespołów klinicznych. GLUT1-DS należy podejrzewać u dzieci, u których występują objawy padaczki lekoopornej o rożnych typach napadów, oraz różnorodne zaburzenia ruchowe o typie dystonii, ataksji, dyskinez, niedowłady spastyczne, zespoły udaropodobne, zaburzenia ruchowe zwłaszcza wywołane wysiłkiem fizycznym lub głodzeniem. Typowo może występować opóźnienie rozwoju psychoruchowego, nabyte małogłowie, różnego stopnia niepełnosprawność intelektualna. Część pacjentów prezentuje nietypowy obraz kliniczny, bez padaczki, z napadowymi zaburzeniami ruchowymi o typie dyskinez, którym mogą towarzyszyć różnego rodzaju nieprawidłowości neurorozwojowe. Taki fenotyp może być mylnie określo- 
ny mianem MPD. Podstawą w diagnostyce GLUT1-DS jest stwierdzenie obniżonego poziomu glukozy w płynie mózgowo-rdzeniowym oraz obniżony stosunek stężenia glukozy w płynie mózgowo rdzeniowym do stężenia glukozy w surowicy krwi. Obecnie przyjmuje się, że wskaźnik ten powinien on być większy niż 0,6 . Leczenie lekami przeciwpadaczkowymi może być nieskuteczne lub nawet potencjalnie szkodliwe. Wczesna identyfikacja pacjentów z GLUT1-DS jest niezwykle ważna, powinni zostać objęci leczeniem dietą ketogenną, która przyczynia się do znacznej poprawy klinicznej i redukcji objawów [31,32].

\section{WYBRANE ZABURZENIA Z DOMINUJĄCYM OBJAWEM ATAKSJI}

\section{Ataksja-teleangiektazja (ataxia-telangiectasia, AT)}

Jest to ciężka wieloukładowa choroba, dziedziczona autosomalnie recesywnie, spowodowana mutacją w genie ATM. Objawia się we wczesnym dzieciństwie postępującą ataksją móżdżkową, dodatkowo na spojówkach i na skórze występują teleangiektazje, charakterystyczne są deficyty immunologiczne oraz tendencje do nowotworzenia. Może również występować dystonia i choreoatetoza. Badanie neuroobrazowe w pierwszych 2 latach życia jest zwykle prawidłowe. Rozwój motoryczny, chodzenie i siedzenie są bardzo zaburzone, a charakterystyczne zmiany skórne pojawiają się później niż ataksja. Obraz kliniczny w pierwszych latach życia może więc sugerować postać móżdżkową MPD i opóźnić prawidłowe rozpoznanie. Ważnym badaniem diagnostycznym jest stwierdzenie podwyższonego poziomu alfa-fetoproteiny w surowicy. Pomimo braku leczenia przyczynowego, wczesne rozpoznanie AT jest szczególnie ważne ze względu na wysokie ryzyko nowotworów złośliwych, a objęcie pacjenta kompleksową opieką lekarską pozwala na wczesne wykrycie i rozpoczęcie leczenia chorób rozrostowych [33].

\section{Choroba Pelizaeusa-Merzbachera}

Choroba ta jest dziedziczona recesywnie z chromosomem X i spowodowana mutacją w genie PLP1, który koduje lipoproteinę 1, główny składnik osłonki mielinowej. Jest to najczęstsza leukodystrofia hipomielinizacyjna typu 1. Pacjenci to najczęściej chłopcy, u których choroba może mieć różne fenotypy. Klasyczna postać choroby rozpoczyna się w okresie niemowlęcym, charakteryzuje się wiotkością, opóźnieniem rozwoju, oczopląsem, ataksją móżdżkową i dyskinezami. Rozwój umysłowy jest różny, od prawidłowego do głębokiego upośledzenia. Lagodna postać, zwana paraparezą spastyczna typu 2, z postępującym niedowładem spastycznym kończyn dolnych, może także występować u kobiet - nosicielek mutacji. W badaniu neuroobrazowym mózgowia stwierdza się rozległą hipomielinizację istoty białej. Ze względu na powolny przebieg wielu chorych może być błędnie zdiagnozowanych jako postać móżdżkowa lub pozapiramidowa MPD [34].

\section{DYSKUSJA}

W niniejszej pracy przedstawiono przykłady chorób neurodegeneracyjnych, genetycznych i metabolicznych, w których współwystępują objawy podobne do MPD. Dla części tych zaburzeń istnieje dostępna forma terapii lub nawet, przy wczesnej interwencji, możliwe jest całkowite wyleczalne. Leach i wsp. w swojej pracy pt. „Treatable inborn errors of metabolism presenting as cerebral palsy: systematic literature review", wśród wrodzonych wad metabolizmu, w których występują objawy imitujące MPD, zidentyfikowali 67 uleczalnych i 43 nieuleczalnych zaburzeń [7]. Choroby te należą do bardzo rzadkich, jednak nie należy ich wykluczać z diagnostyki różnicowej MPD. Dużą część z nich można zidentyfikować w sposób mało inwazyjny i na wczesnym etapie, dzięki programowi badań przesiewowych noworodków. Inne wymagają wykonania punkcji lędźwiowej i badania płynu mózgowo rdzeniowego pod kątem nieprawidłowości dotyczących np. neuroprzekaźników lub glukozy. Jest to szczególnie ważne $\mathrm{u}$ niemowląt i dzieci ze zmiennymi w czasie, napadowymi zaburzeniami ruchowymi. Inne badania, neuroobrazowanie i molekularne testy genetyczne ułatwiają diagnozę i poznanie patofizjologii tych zaburzeń. Biorąc pod uwagę znaczny postęp w diagnostyce genetycznej w ostatnim dziesięcioleciu, w pewnych przypadkach należałoby rozważyć ponowną weryfikację rozpoznania MPD, szczególnie u pacjentów nastoletnich i dorosłych, u których nie jest jasna przyczyna istniejących zespołów neurologicznych. Uzasadnieniem takiego działania nie ma być chęć zmiany diagnozy MPD, lecz raczej poprawa zrozumienia, klasyfikacji MPD przez poznanie patomechanizmu zaistniałych zaburzeń.

Fakt, iż wraz z rozwojem medycyny zaawansowane badania odkrywają wiele genetycznych i metabolicznych przyczyn MPD, wywołuje silną dyskusję wśród klinicystów, czy diagnoza kliniczna porażenia mózgowego powinna zostać zrewidowana w przypadku ustalenia etiologii. W kwietniu 2018 w Zhengzhou w Chinach odbyło się spotkanie ekspertów zrzeszonych w Międzynarodowym Konsorcjum Genomiki Porażenia Mózgowego (The International Cerebral Palsy Genomics Consortium ICPGC). Wyraźny konsensus był taki, że diagnoza kliniczna porażenia mózgowego nie powinna ulegać zmianie pomimo zidentyfikowania przyczyny genetycznej lub niegenetycznej, jeśli dana osoba wykazuje niepostępujące trwałe zaburzenie ruchu i postawy. Istnieją jasne korzyści z rozpoznania i nazwania zespołu objawów mianem MPD. Jest to pomocne dla organizacji opieki nad pacjentem, zapewnia lepszy dostęp do usług, wsparcie finansowe i społeczne oferowane rodzinom. Takie rozpoznanie jest również bardziej zrozumiałe i akceptowane wśród ogółu społeczeństwa [35].

\section{PIŚMIENNICTWO}

[1] Rosenbaum P., Paneth N., Leviton A. et al.: A report: the definition and classification of cerebral palsy April 2006. Dev Med Child Neurol Suppl. 2007 Feb;109:8-14. Erratum in: Dev Med Child Neurol. 2007; 49: 480.

[2] Johnson A.: Prevalence and characteristics of children with cerebral palsy in Europe. Dev Med Child Neurol. 2002; 44: 633-640.

[3] Michałowicz R: Mózgowe porażenie dziecięce. Wydawnictwo Lekarskie PZWL, Warszawa 2001; 17-26. 
[4] Durkin M.S., Benedict R.E., Christensen D., et al.: Prevalence of Cerebra Palsy among 8-Year-Old Children in 2010 and Preliminary Evidence of Trends in Its Relationship to Low Birthweight. Paediatr Perinat Epidemiol. 2016; 30: 496-510.

[5] Prevalence and Incidence of Cerebral Palsy. (n.d.). Retrieved September 2, 2014, from http://cerebralpalsy.org/about-cerebral-palsy/prevalenceof-cerebral-palsy/

[6] Bennett J.F., Andrews M., Omura J.: Cerebral Palsy: Etiology, Evaluation, and Management of the Most Common Cause for Pediatric Disability. Physician Assistant Clinics, 2020; 5: 525-538.

[7] Leach E.L., Shevell M., Bowden K. et al.: Treatable inborn errors of metabolism presenting as cerebral palsy mimics: systematic literature review. Orphanet J Rare Dis. 2014; 30: 197.

[8] Pearson T.S., Pons R., Ghaoui R., et al.: Genetic mimics of cerebral palsy. Mov Disord. 2019; 34: 625-636.

[9] Lingen M., Albers L., Borchers M., et al.: Obtaining a genetic diagnosis in a child with disability: impact on parental quality of life. Clin Genet. 2016; 89: 58-266.

[10]. Graham H.K., Rosenbaum P., Paneth N., et al.: Cerebral palsy. Nat Rev Dis Primers. 2016; 7: 15082.

[11] Colver A., Fairhurst C., Pharoah P.0.: Cerebral palsy. Lancet. 2014; 383: 1240-1249.

[12] Hedera P.: Hereditary Spastic Paraplegia Overview. 2000 Aug 15 [updated 2021 Feb 11]. In: Adam MP, Ardinger HH, Pagon RA, Wallace SE, Bean LJH, Mirzaa G, Amemiya A, editors. GeneReviews ${ }^{\circledR}$ [Internet]. Seattle (WA): University of Washington, Seattle; 1993-2021.

[13] Fink J.K.: Hereditary spastic paraplegia: clinico-pathologic features and emerging molecular mechanisms. Acta Neuropathol. 2013; 126: 307 328.

[14] Rainier S., Sher C., Reish 0., et al.: De novo occurrence of novel SPG3A/ atlastin mutation presenting as cerebral palsy. Arch Neurol. 2006; 63: 445-447.

[15] Scheuerle A.E., McVie R., Beaudet A.L., et al.: Arginase deficiency presenting as cerebral palsy. Pediatrics. 1993; 91: 995-996.

[16] Prasad A.N., Breen J.C., Ampola M.G., et al.: Argininemia: a treatable genetic cause of progressive spastic diplegia simulating cerebral palsy: case reports and literature review. J Child Neurol. 1997; 12: 301-309.

[17] Wolf B.: The neurology of biotinidase deficiency. Mol Genet Metab. 2011; 104: 27-34.

[18] Wiznitzer M., Bangert B.A.: Biotinidase deficiency: clinical and MR findings consistent with myelopathy. Pediatr Neurol. 2003; 29: 56-58.

[19] Livne M., Gibson K.M., Amir N., et al.: Holocarboxylase synthetase deficiency: a treatable metabolic disorder masquerading as cerebral palsy. J Child Neurol. 1994; 9: 170-172.

[20] Pronicka E., Sykut-Cegielska J., Sawnor-Orszyńska D., et al.:, Wynik pilotażowego badania w kierunku deficytu biotynidazy: za i przeciw wprowadzeniu skriningu populacyjnego noworodków w Polsce. Ped Pol 1996; 10: 851-856
[21] Kurian M.A., Gissen P., Smith M., et al.: The monoamine neurotransmitter disorders: an expanding range of neurological syndromes. Lancet Neurol. 2011; 10: 721-733.

[22] Szymańska K., Kuśmierska K., Mierzewska H.: Wrodzone zaburzenia metabolizmu amin biogennych i pteryn. NEUR, CHILD. 2007; 16: 41-50.

[23] Patel N.J., Jankovic J.: NKX2-1-Related Disorders. 2014 Feb 20 [Updated 2016 Jul 29]. In: Adam MP, Ardinger HH, Pagon RA, et al., editors. GeneReviews ${ }^{\circledR}$ [Internet]. Seattle (WA): University of Washington, Seattle; 1993-2021. Address: https://www.ncbi.nlm.nih.gov/books/ NBK185066

[24]. Carré A., Szinnai G., Castanet M., Sura-Trueba S., et al.: Five new TTF1/ NKX2.1 mutations in brain-lung-thyroid syndrome: rescue by PAX8 synergism in one case. Hum Mol Genet. 2009; 18: 2266-2276.

[25] Peall K.J., Lumsden D., Kneen R., et al.: Benign hereditary chorea related to NKX2.1: expansion of the genotypic and phenotypic spectrum. Dev Med Child Neurol. 2014; 56: 642-648.

[26] Torres R.J., Puig J.G.: Hypoxanthine-guanine phosophoribosyltransferase (HPRT) deficiency: Lesch-Nyhan syndrome. Orphanet J Rare Dis. 2007; 8: 48.

[27] Carecchio M., Mencacci N.E., lodice A., et al.: ADCY5-related movement disorders: Frequency, disease course and phenotypic variability in a cohort of paediatric patients. Parkinsonism Relat Disord. 2017; 41: 3743.

[28] Ogier de Baulny H., Saudubray J.M.: Branched-chain organic acidurias. Semin Neonatol. 2002; 7: 65-74.

[29] Stockler-Ipsiroglu S., Mercinek-Mahmutoglu S., Salomons G.: Creatine deficiency syndromes. In: Saudubray JM, van den Berghe Georges, Walter JH, eds. Inborn Metabolic Diseases. Diagnosis and Treatment. 6th ed. Springer-Verlag; 2016: 243-248.

[30] Lewandowska Z., Steinborn B., Borkowski W. et al.: SCL6A8 mutation in female patient resulting in creatine transporter deficiency, NEUR, CHILD. Vol. . 27/2018, nr 55: 69-76.

[31] Verrotti A., D'Egidio C., Agostinelli S., et.al.: Glut1 deficiency: when to suspect and how to diagnose? Eur J Paediatr Neurol. 2012; 16: 3-9.

[32] Winczewska-Wiktor A., Hoffman-Zacharska D., Starczewska M., et al.: Variety of symptoms of GLUT1 deficiency syndrome in three-generation family. Epilepsy Behav. 2020 ;106: 107036.

[33] Rothblum-Oviatt C., Wright J., Lefton-Greif M.A., et al.: Ataxia telangiectasia: a review. Orphanet J Rare Dis. 2016; 11: 159

[34] Hobson G.M., Garbern J.Y.: Pelizaeus-Merzbacher disease, PelizaeusMerzbacher-like disease 1, and related hypomyelinating disorders. Semin Neurol. 2012; 32: 62-67.

[35] MacLennan A.H., Lewis S., Moreno-De-Luca A., et al.: Genetic or Other Causation Should Not Change the Clinical Diagnosis of Cerebral Palsy. J Child Neurol. 2019; 34: 472-476. 